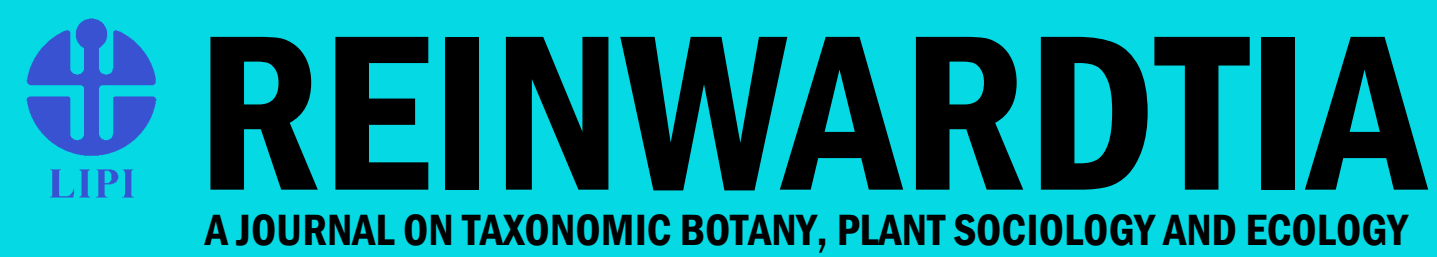

ISSN 0034 - 365 X | E-ISSN 2337 - 8824 | Accredited 792/AU3/P2MI-LIPI/04/2016
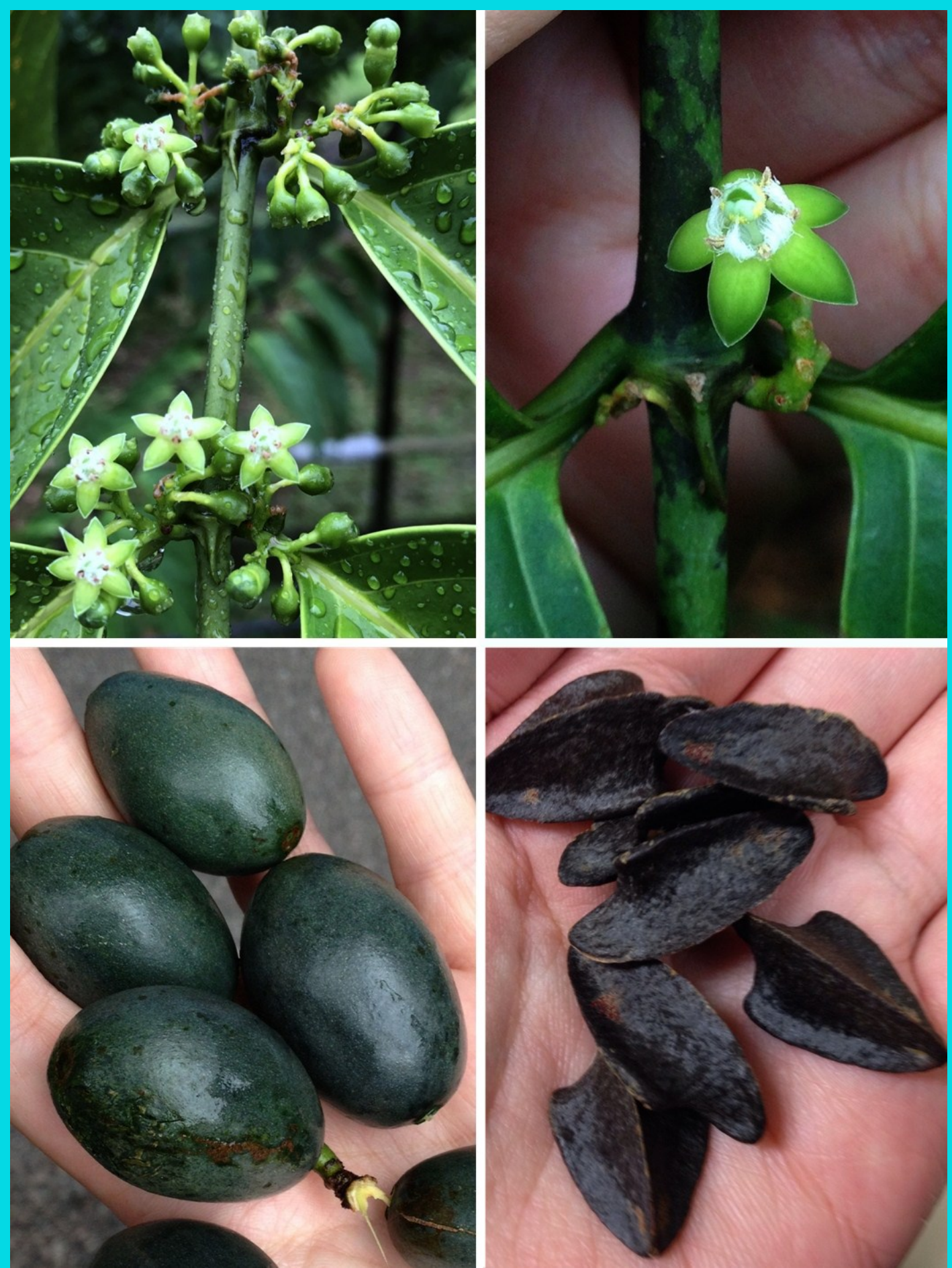

$201817(2)$ 


\section{REINWARDTIA}

\section{A JOURNAL ON TAXONOMIC BOTANY, PLANT SOCIOLOGY AND ECOLOGY}

Vol. 17 (2): 87 - 154, December 18, 2018

\section{Chief Editor}

Kartini Kramadibrata (Mycologist, Herbarium Bogoriense, Indonesia)

\section{Editors}

Dedy Darnaedi (Taxonomist, Herbarium Bogoriense, Indonesia)

Tukirin Partomihardjo (Ecologist, Herbarium Bogoriense, Indonesia)

Joeni Setijo Rahajoe (Ecologist, Herbarium Bogoriense, Indonesia)

Marlina Ardiyani (Taxonomist, Herbarium Bogoriense, Indonesia)

Himmah Rustiami (Taxonomist, Herbarium Bogoriense, Indonesia)

Lulut Dwi Sulistyaningsih (Taxonomist, Herbarium Bogoriense, Indonesia)

Topik Hidayat (Taxonomist, Indonesia University of Education, Indonesia)

Eizi Suzuki (Ecologist, Kagoshima University, Japan)

Jun Wen (Taxonomist, Smithsonian Natural History Museum, USA)

Barry J. Conn (Taxonomist, School of Life and Environmental Sciences, The University of Sydney, Australia)

David G. Frodin (Taxonomist, Royal Botanic Gardens, Kew, United Kingdom)

Graham Eagleton (Wagstaffe, NSW, Australia)

\section{Secretary}

Ruslan Bukhori

\section{Layout}

Liana Astuti

\section{Illustrators}

Subari

Wahyudi Santoso

Anne Kusumawaty

Correspondence on editorial matters and subscriptions for Reinwardtia should be addressed to:

HERBARIUM BOGORIENSE, BOTANY DIVISION,

RESEARCH CENTER FOR BIOLOGY - INDONESIAN INSTITUTE OF SCIENCES

CIBINONG SCIENCE CENTER, JLN. RAYA JAKARTA - BOGOR KM 46,

CIBINONG 16911, P.O. Box 25 CIBINONG

INDONESIA

PHONE (+62) 21 8765066; Fax (+62) 218765062

E-MAIL: reinwardtia@mail.lipi.go.id

http://e-journal.biologi.lipi.go.id/index.php/reinwardtia

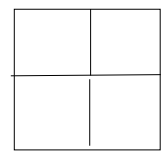

Cover images: Canthiumera robusta K.M.Wong \& X.Y.Ng, spec. nov. Top left: leafy branch with inflorescences; note also keeled stipules. Top right: flower with tufts of pale moniliform hairs visible opposite corolla lobes. Below left: fruits. Below right: pyrenes. Photos: Ang Wee Foong (top left) and X.Y. Ng (remaining images). 
The Editors would like to thank all reviewers of volume 17(2):

Andrew Powling, School of Biological Sciences, University of Portsmouth, Portsmouth, United Kingdom George Argent, Royal Botanic Garden Edinburgh, Edinburgh, United Kingdom

Joan Pereira, Forest Research Centre, Sandakan, Sabah, Malaysia

Jun Yokoyama, Dept. of Biology, Faculty of Science, Yamagata University, Yamagata, Japan

Khoon Meng Wong, Singapore Botanic Gardens, Singapore

Kongkanda Chayamarit, Queen Sirikit Botanic Garden, P.O. Box 7, Mae Rim, Chiang Mai, Thailand 


\title{
ECOLOGICAL STUDY OF THE ARROWROOT (Tacca leontopetaloides (L.) Kuntze) AT KARIMUNJAWA NATIONAL PARK, CENTRAL JAVA
}

\author{
Received 02 April, 2018; accepted 04 October, 2018
}

\section{LAODE ALHAMD}

Herbarium Bogoriense, Botany Division, Research Center for Biology-LIPI, Cibinong Science Center, Jln. Raya Jakarta-Bogor Km. 46, Cibinong, 16911, Bogor, Indonesia. Email: aruhamu@yahoo.com

\begin{abstract}
ALHAMD, L. 2018. Ecological study of the arrowroot (Tacca leontopetaloides (L.) Kuntze) at Karimunjawa National Park, Central Java. Reinwardtia 17(2): 87-96. - An ecological study of arrowroot (Tacca leontopetaloides (L.) Kuntze) at Karimunjawa National Park (Karimunjawa NP), Central Java, was conducted at six islands, namely Kumbang, Nyamuk, Katang, Seruni, Cendikia and Sintok islands. A sampling plot of $10 \times 50 \mathrm{~m}^{2}$ was established on each island. The results showed that the arrowroot population in Katang island was greater than those of other islands, with a density of $0.74 \mathrm{~m}^{-2}$, a frequency of 0.8 and an abundance of 23.1 . The arrowroot density of all samplings ranged from 137 to 370 per 0.05 ha. The occurrence of 30 species surrounding arrowroot was observed and only five species, Sida acuta (Chi-square count $(\mathrm{cs})>$ Chi-square table $\mathrm{cs}=5.71, \mathrm{P}<0.05)$ and Scaevola taccada $(\mathrm{cs}=7.94, \mathrm{P}<0.01)$ in Kumbang island, Imperata cylindrica $(\mathrm{cs}=18.81, \mathrm{P}<0.01)$ in Nyamuk island, Morinda citrifolia $(\mathrm{cs}=9.47, \mathrm{P}<0.01)$ in Sintok island, and Carica papaya $(\mathrm{cs}=3.95, \mathrm{P}<0.05)$ in Cendikia island, had significant associations with arrowroot. For habitat characteristics, soil textures were dominated by sandy types ranging from 90 to $95 \%$, whilst other soil properties such as $\mathrm{pH}, \mathrm{N}, \mathrm{P}, \mathrm{K}, \mathrm{Mg}$ and $\mathrm{CEC}$ did not significantly affect the presence of arrowroot.
\end{abstract}

Key words: Cendikia, Katang, Kumbang, Nyamuk, Seruni and Sintok islands, soil, species association.

\begin{abstract}
ABSTRAK
ALHAMD, L. 2018. Studi ekologi taka (Tacca leontopetaloides (L.) Kuntze) di Taman Nasional Karimunjawa, Jawa Tengah. Reinwardtia 17(2): 87-96. - Kajian ekologi taka (Tacca leontopetaloides (L.) Kuntze) di Taman Nasional Karimunjawa (TN Karimunjawa), Jawa Tengah, dilakukan di enam pulau, yaitu pulau Kumbang, Nyamuk, Katang, Seruni, Cendikia dan Sintok. Sebuah petak contoh seluas $10 \times 50 \mathrm{~m}^{2}$ dibuat di masing-masing pulau. Hasil penelitian menunjukkan bahwa populasi taka di pulau Katang lebih besar daripada populasi pulau lainnya, dengan kepadatan $0,74 \mathrm{~m}^{-2}$, frekuensi 0,8 dan kelimpahan 23,1. Kepadatan taka di seluruh petak contoh berkisar antara 137 hingga 370 per 0,05 ha. Terdapat 30 jenis tumbuhan di sekitar taka yang teramati dan hanya lima jenis, Sida acuta (Chi-square count (cs) $>$ tabel Chi-square cs $=5.71, \mathrm{P}<0.05)$ dan Scaevola taccada $(\mathrm{cs}=7,94, \mathrm{P}<0,01)$ di pulau Kumbang, Imperata cylindrica $(\mathrm{cs}=18,81, \mathrm{P}<0,01)$ di pulau Nyamuk, Morinda citrifolia $(\mathrm{cs}=9,47, \mathrm{P}<0,01)$ di pulau Sintok, dan Carica papaya $(\mathrm{cs}=3,95, \mathrm{P}<0,05)$ di pulau Cendikia, yang memiliki asosiasi signifikan pada taka. Pada karakteristik habitat, tekstur tanah didominasi oleh tipe berpasir dengan kisaran antara 90 hingga $95 \%$, sementara sifat-sifat tanah lainnya seperti $\mathrm{pH}, \mathrm{N}, \mathrm{P}, \mathrm{K}, \mathrm{Mg}$ dan KTK (Kapasitas Tukar Kation) tidak berpengaruh secara signifikan terhadap keberadaan taka.
\end{abstract}

Kata kunci: Asosiasi jenis, Pulau Cendikia, Katang, Kumbang, Nyamuk, Seruni dan Sintok, tanah.

\section{INTRODUCTION}

Climate change will probably have a negative impact on the production and quality of food plants in Indonesia (Chozin, 2012). Rice is a main source of food stuffs in Indonesia and its role is the most crucial in food provision and national food security.

In several locations, such as cultivated paddy, recent production is decreasing due to decreasing area, the impact of diseases and pests, and catastrophe in the case of flash floods that sometimes cause damage to rice fields. Effects of climate change, land use and decreasing productivity of the land are also factors that limit potential food production, for instance in coastal areas. Food self-sufficiency can be pursued by utilizing the local biological food resources that have a nutrient content similar to other main crops.
The arrowroot (Tacca leontopetaloides (L.) Kuntze) usually grows in coastal areas, including on small islands such as those around Karimunjawa National Park (KNP), Central Java. Tubers of the plant can be used as a carbohydrate source, when high tides prevent access to get commercial food sources in the mainland of Java. Although arrowroot is a bulbous plant with high carbohydrate content, it has not been much exploited and potentially can be used as a food resource in Indonesia. As a perennial plant and belong to the family Taccaceae, the arrowroot usually grows in understory of humid and seasonal tropical and subtropical rain forest. Arrowroot is perennial with erect plant. Rhizomes cylindric to subcylindric or tubers globose to broadly obovate. Leaves 1-3, broadly obovate, ovate or oblong-ovate. Flowers pedicelled and arranged in an umbel, nacked, greenish to yellow 
(Meena \& Yadav, 2010).

A study has been made on arrowroot biomass correlated to plant diameter on some islands around Karimunjawa NP (Alhamd, 2012). However, ecological studies investigating arrowroot growth in Karimunjawa NP are still limited, in particular there is a lack of information concerning distribution, soil nutrients and species association that might play a role in the life of this plant. Thus, ecological studies of arrowroot on several islands around Karimunjawa NP are needed. This present study concerns the development and ecology of arrowroot that could be used to support species role in national food security.

\section{MATERIALS AND METHODS}

\section{Study Site}

Karimunjawa NP administratively belongs to Jepara district, Central Java. The islands have native ecosystems with high biodiversity ranging from coastal areas to lowland. The local community deeply depends on natural resources on the island.

Karimunjawa NP is coastal lowland covered by mangrove forests. Beach areas mostly consist of white sand. Fringing reefs protect the shoreline from waves. Thus, the shoreline of Karimunjawa NP differs from steep coast. The forest area covers approximately 2,888 ha. The NP is located 45 miles northeast of the city of Jepara, or 60 miles northeast of Semarang City.

In terms of rainfall, according to Schmidt and Ferguson (1951), the Karimunjawa NP is in E type, indicating a slightly dry climate. The climate diagram for Karimunjawa NP, based on Walter
(1973), shows a decrease of rainfall from July up to the drought period from August $(42 \mathrm{~mm})$ to October $(55 \mathrm{~mm})$, and a wet period between November $(147 \mathrm{~mm})$ and March $(297 \mathrm{~mm})$ with the highest rainfall in January (524 mm). During August to September, the evapotranspiration is assumed to exceed the rainfall (Fig. 1).

The ecological study of arrowroot plants was conducted on six islands located around the Karimunjawa NP, namely Kumbang island $\left(5^{\circ} 45^{\prime}\right.$ 23.9" $\mathrm{S}$ and $\left.110^{\circ} 14^{\prime} 35.6^{\prime \prime} \mathrm{E}\right)$, Nyamuk island $\left(5^{\circ}\right.$ $47^{\prime} 54.9^{\prime \prime} \mathrm{S}$ and $\left.110^{\circ} 8^{\prime} 38.3^{\prime \prime} \mathrm{E}\right)$, Katang island (5 $48^{\prime} 55.1^{\prime \prime} \mathrm{S}$ and $\left.110^{\circ} 11^{\prime} 3.96^{\prime \prime} \mathrm{E}\right)$, Seruni island ( $5^{\circ}$ 51' 28.0" $\mathrm{S}$ and $110^{\circ} 36^{\prime} 9.38^{\prime \prime} \mathrm{E}$ ), Cendikia island ( $5^{\circ} 47^{\prime} 52.2^{\prime \prime} \mathrm{S}$ and $110^{\circ} 33^{\prime} 33.1^{\prime \prime} \mathrm{E}$ ) and Sintok island ( $5^{\circ} 46^{\prime} 45.1^{\prime \prime} \mathrm{S}$ and $\left.110^{\circ} 30^{\prime} 52.4^{\prime \prime} \mathrm{E}\right)$, as shown in Fig. 2. The focus on these islands as the study site was based on information from previous studies (Setyowati et al., 2012; Wawo et al., 2015), and also because the people of the islands use the plant as an alternative food.

\section{Methods}

In this study, observations were carried out in sampling plots. A sampling plot of $10 \mathrm{~m} \times 50 \mathrm{~m}$ was established on each island perpendicular to the shoreline. Each plot was divided into ten sub-plots of $5 \mathrm{~m} \times 5 \mathrm{~m}$. The number of individuals/clumps, height, stem diameter, coordinate of the plant within each sub-plot ( $\mathrm{x}$ and y coordinates), crown coverage and number of flowers and fruit were measured and recorded. Other plants found within the plot were also recorded. Soil samples of approximately one $\mathrm{kg}$ at five points inside and two points outside each sampling point were collected in polybags. The soil properties such as $\mathrm{pH}$, textures and soil nutrients $\mathrm{N}, \mathrm{P}, \mathrm{K}, \mathrm{Ca}, \mathrm{Mg}$ and

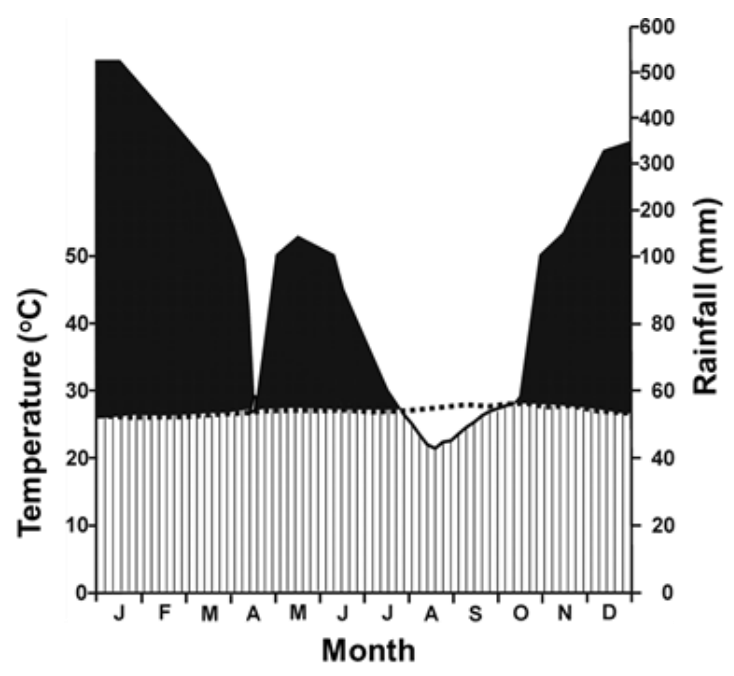

Fig. 1. Climate diagram for Karimunjawa weather station (Walter, 1973). The data for rainfall and temperature in 2015 were accessed on climate-data.org (September $6^{\text {th }}$ 2016). 


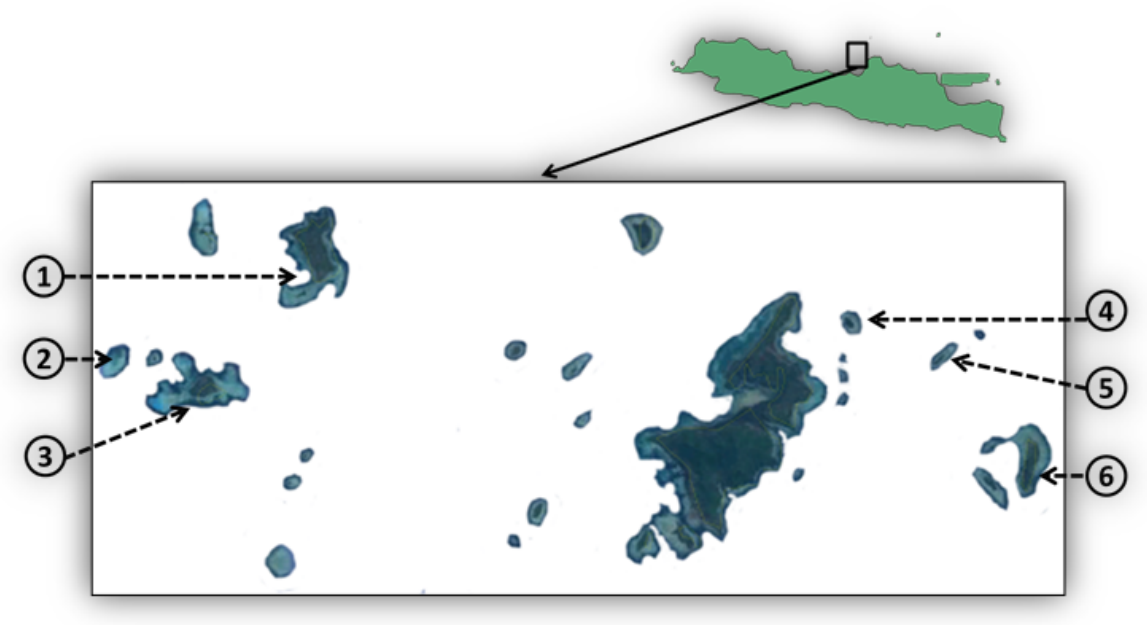

Fig. 2. The location of sampling plots in Karimunjawa National Park (NP), Central Java. Kumbang island (1) Nyamuk island (2); Katang island (3); Sintok island (4); Cendikia island (5) and Seruni island (6).

CEC (Cation Change Capacity) were analyzed in Soil Laboratoy of Agricultural Research Center, Minister of Agriculture, Bogor. Also, Canonical Correlation Analysis (CCA) of PAST 3.18 Programme was used to observe the correlation between soil nutrient and arrowroot population. T-test analysis in Excel was utilized to compared diameter and height of arrowroot plants with onetail distribution and two-sample unequal variance.

\section{Data analysis}

The density (individuals $\mathrm{m}^{-2}$ ), the frequency and the abundance/dominance of arrowroot, were calculated by the following formulas:

Density (D)

$$
\mathrm{D}=\frac{\text { Number of individual arrowroot plants }}{\text { Area size of collected sample }}
$$

Frequency (F)

$$
\mathrm{F}=\frac{\text { Number of sub }- \text { plots with arrowroot }}{\text { Total number of sub }- \text { plots }}
$$

Abundance (A)

$$
A=\frac{\text { Number of individual arrowroot in all sampling sub }- \text { plots }}{\text { Total number of sub }- \text { plots }}
$$

Association analysis was performed on the arrowroot and other species, using $2 \times 2$ contingency tables (Mueller-Dombois \& Ellenberg, 1974). The form of contingency table for the two species was as follows:

\begin{tabular}{ccccc}
\hline & & \multicolumn{2}{c}{ B Species } & \multirow{2}{*}{ Total } \\
\cline { 3 - 4 } & & Presence & Absence & \\
\hline \multirow{2}{*}{ A Species } & Presence & $\mathrm{a}$ & $\mathrm{B}$ & $(\mathrm{a}+\mathrm{b})$ \\
& Absence & $\mathrm{c}$ & $\mathrm{D}$ & $(\mathrm{c}+\mathrm{d})$ \\
\hline \multicolumn{2}{c}{ Total } & $(\mathrm{a}+\mathrm{c})$ & $(\mathrm{b}+\mathrm{d})$ & $\mathrm{N}=\mathrm{a}+\mathrm{b}+\mathrm{c}+\mathrm{d}$ \\
\hline
\end{tabular}

Note: $\mathrm{a}=$ Number of measurement points containing both $\mathrm{A}$ and $\mathrm{B}$ species, $\mathrm{b}=$ Number of measurement points containing only A species, $c=$ Number of measurement points containing only $B$ species, $d=$ measurement points in which both $\mathrm{A}$ and $\mathrm{B}$ species were not found, $\mathrm{N}=$ total number of measurements.

To determine the significance of the trend of association (or not), a Chi-square value was calculated with the following formula:

Chi - square calculation $=\frac{N(a d-b c) 2}{a+b a+c c+d(b+d)}$

The Chi-square value was then compared with the value of Chi-square in a table of significance values at the $1 \%$ and $5 \%$ levels with degrees of freedom $(\mathrm{df})=1$. If the value of Chi-square Calculated $>$ Chi-square table value, then the association is significant. If the value of Chi-square calculated $<$ Chi-square table value, then the association is not significant (Ludwig \& Reynold, 1988). Furthermore, to determine the level of association the following formula is used:

$$
E(a)=\frac{(a+b)(a+c)}{N}
$$

Where the notation has the same meanings as the contingency tables. 


\section{RESULTS}

Arrowroot is a wild tuber-producing plant but few people utilize the tuber. The results showed that arrowroot occurs naturally on the six islands in Karimunjawa NP and grows in coastal areas close to the shoreline.

\section{Ecological Study}

Overall, the density, frequency and abundance of arrowroot differed between the islands. The highest density as well as abundance were recorded on Katang island (Table 1).

\section{Kumbang Island}

The density of arrowroot on Kumbang island was higher than on Nyamuk and Sintok islands but lower than Katang, as shown in Table 1. The presence of distribution/frequency of arrowroot on this island was lower than in the other five sampling plots on Nyamuk, Katang, Seruni, Cendikia and Sintok islands. Plant heights lower than $20 \mathrm{~cm}$ reached $34.2 \%$, and diameters less than $1 \mathrm{~cm}$ reached $73.1 \%$ of the total arrowroot in the sampling plot. This location has a rather flat topography, with sandy soils (>90\%). Arrowroot was found approximately $20 \mathrm{~m}$ from the shoreline. Besides arrowroot, sixteen other species were found in the sampling plot, including Premna corymbosa, Guettarda speciosa and Litsea accedentoides.

\section{Nyamuk Island}

The density and the abundance were slightly higher than on Sintok island, as shown in Table 1. Height lower than $20 \mathrm{~cm}$ made up $11.8 \%$ and diameters lower than $1 \mathrm{~cm}$ reached $68.0 \%$ of the total individual arrowroots in the plot. The island has a rather flat topography, with sandy soils greater than $90 \%$. Arrowroot was found far from residential areas, because the plant was not the main source for the community. The arrowroot naturally grows in former fields. The other two dominating species in the sampling plot were Imperata cylindrica and Scaevola taccada, while I. cylindrica was found with arrowroot in a previous farming area.

\section{Katang Island}

The density and abundance of arrowroot were somewhat higher than in other sampling plots, as shown in Table 1. Plant heights were commonly greater than $20 \mathrm{~cm}$ and diameters of more than 1 $\mathrm{cm}$ reaching $99 \%$ of the total arrowroot in the plot. As with the two previous islands, this area has a flat topography and the soils are dominated by sandy content (>90\%). Arrowroot was found up to approximately $20-30 \mathrm{~m}$ from the shoreline. Of the eight other species in the sampling plot, Cocos nucifera and Premna corymbosa were common.

\section{Seruni Island}

The frequency and abundance of arrowroot in this area were highest, although the plant grew in the farmed and burned areas. Also, the plant was uniformly distributed in the sampling plot with a high frequency value (Table 1). Topography is similar to the other islands, with sandy content reaching $>90 \%$. There were no plants having a height lower than $20 \mathrm{~cm}$ and those with diameters less than $1 \mathrm{~cm}$ reached $24.7 \%$ of the total individual arrowroots. Of the other nine plants that grew in the sampling plot, Glochidion litorale, Sida acuta and Amorphophallus muelleri were prominent.

\section{Cendikia Island}

The density and the abundance of arrowroot in this area were slightly higher than those of Nyamuk and Sintok islands. The arrowroot on this island was more dispersed than Kumbang, Nyamuk and Katang Islands, as shown in Table1. The island has a relatively flat topography and soil properties were sandy (sandy content $>90 \%$ ). Arrowroot is also found up to $19 \mathrm{~m}$ of the shoreline. Plants lower than $20 \mathrm{~cm}$ in height reached $0.5 \%$ and those with a diameter less than $1 \mathrm{~cm}$ amounted to $9.2 \%$ of the total arrowroot in the plot. Other prominent plants in the sampling plot, out of 14 species, were Cocos nucifera, Glochidion littorale and Guettarda speciosa.

\section{Sintok Island}

The density and the abundance of arrowroot were the lowest compared to the other sampling plots, shown in Table 1, which could be caused by the open area with no shading trees. Topography is similar to the other five islands and soils have high sandy contents. Arrowroot was found close to the shoreline, to approximately $10 \mathrm{~m}$. Arrowroot plants lower than $20 \mathrm{~cm}$ amounted to $1.5 \%$, those with the diameter less than $1 \mathrm{~cm}$ were 55 individuals or $40.7 \%$ of the total arrowroot in the plot. The species Glochidion littorale and Premna corymbosa, out of eleven species, dominated in the sampling plot.

Arrowroot structure vertically and horizontally, in several sampling plots, showed different patterns for both height and diameter (Figs. 3 and 4). The vertical structure was dominated by arrowroot height greater than $50 \mathrm{~cm}$ in Nyamuk, Katang, Seruni and Cendikia islands, with a tendency for the density on Seruni and Cendikia Islands to increase with increasing plant height. The arrowroot population on Sintok island was common by $30-40 \mathrm{~cm}$ height class, while in Kumbang island, small arrowroot was more abundant than on other islands, with a range of heights from 5 to $20 \mathrm{~cm}$. The different structures of the plant, based on all sampling plots, were highly significant, with the exceptions of Katang 
Table 1. The density (D), frequency (F) and abundance (A) of arrowroot, in several sampling areas surrounding Karimunjawa NP, Central Java.

\begin{tabular}{ccccc}
\hline No. & Location (Island) & D (individuals $\mathbf{~ m}^{-2}$ ) & F & A \\
\hline 1 & Kumbang & 0.47 & 0.7 & 16.7 \\
2 & Nyamuk & 0.29 & 0.8 & 8.47 \\
3 & Katang & 0.74 & 0.8 & 23.1 \\
4 & Seruni & 0.47 & 1.0 & 11.6 \\
5 & Cendikia & 0.35 & 0.9 & 9.72 \\
6 & Sintok & 0.27 & 0.9 & 7.61 \\
\hline
\end{tabular}

and Seruni islands $(\mathrm{T}$-test $=0.227, \mathrm{P}>0.01)$. The horizontal structure, based on the diameters, showed a tendency for the diameter class $1 \leq 2.5$ $\mathrm{cm}$ to increase and then decrease on Katang, Cendikia and Sintok islands, while decreasing patterns occurred in Kumbang, Nyamuk and Seruni islands. A high number of individuals within the diameter interval of 2 to $\geq 2.5 \mathrm{~cm}$ was found in Katang and Cendikia islands. Different patterns were shown on the Kumbang and Nyamuk islands which were dominated by arrowroot with diameters from 0 to less than $0.5 \mathrm{~cm}$. The differences in the diameters of arrowroot between sampling sites were highly significant, with the exception of the Kumbang and Nyamuk islands (T-test $=0.48, \mathrm{P}>0.05)$ and between Sintok and Seruni Islands $(\mathrm{T}$-test $=0.049, \mathrm{P}>0.01)$.

\section{DISCUSSION}

Arrowroot is distributed in Africa, Southeast Asia, Australia and Pacific islands. Arrowroot thrives well in areas protected from salt that are only slightly shaded and well drained (Meena \& Yadav, 2010; Spennemann, 1994), although a small population of the plant in montane forest was recently recorded on Bawean island (Trimanto \& Hapsari, 2016). In the study plots, the arrowroot was widely distributed near the shoreline, but the plant was not exposed to salt from the sea.

An important note, the number of seedlings of arrowroot on Katang island might have resulted from spreading of the plants naturally. Generally, this begins with an arrowroot that has a height of more than $65 \mathrm{~cm}$ (field observation) that falls down after flowering and fruiting, so its stalk will fall close to the plant, thus the spreading process of arrowroot starts in groups of seedlings which were lower than $20 \mathrm{~cm}$ in height. Then the seedlings will compete and are naturally selected to grow into larger plants. The life cycle of arrowroot from seedling up to the production of tubers takes 3-6 months, according to the local community (pers. comm.), while 24 weeks after planting the arrowroot will produce both peripheral and parent tubers (Wawo et al., 2015).

Katang island showed the highest density and abundance, with 15 sampling sub-plots having arrowroot ranging from 30 to 90 individuals, most of the plants being in the seedling stage. Lower frequencies indicate that several sub-plots were without arrowroot. Contrary to three other sampling plots, Seruni, Cendikia and Sintok islands, the arrowroot plants were almost distributed uniformly with low individual numbers. The difference between Katang and the other three islands could be attributed to the continuing vegetative to generative phases with some seedlings and some arrowroot producing flowers and fruits in Katang. While generative phase plants were only found on Seruni and Cendikia islands that indicated that no/few seedlings found and most of arrowroot produced flowers and fruits. In contrast to Sintok island, the arrowroot was continuing the last of vegetative phase. The different stages of their life cycle among islands could not be explained because of the uncultivated/wild plant.

Arrowroot stems and leaves normally have green colour during the vegetative phase. The yellowish leaves of young arrowroot were mostly found in open areas such as on Katang and Seruni islands, because the plants received direct sunlight, even though the arrowroot, as a shade tolerant plant, needs limited sunlight during the vegetative phase. Alternatively, yellowish leaves could also be attributed to human factors, in which the areas with burning system were previously used by people as agricultural land. The system indirectly contribute to the low nutrients in the soil with releasing organic materials. Then, the opening areas surrounding arrowroot could influence the longevity period of existing flowers, few small flowers and dried fruits produce, as recorded in Katang island.

The relationships between arrowroot height and number of flowers/ fruits were assessed using flower and fruit data, as shown in Fig. 5. More 


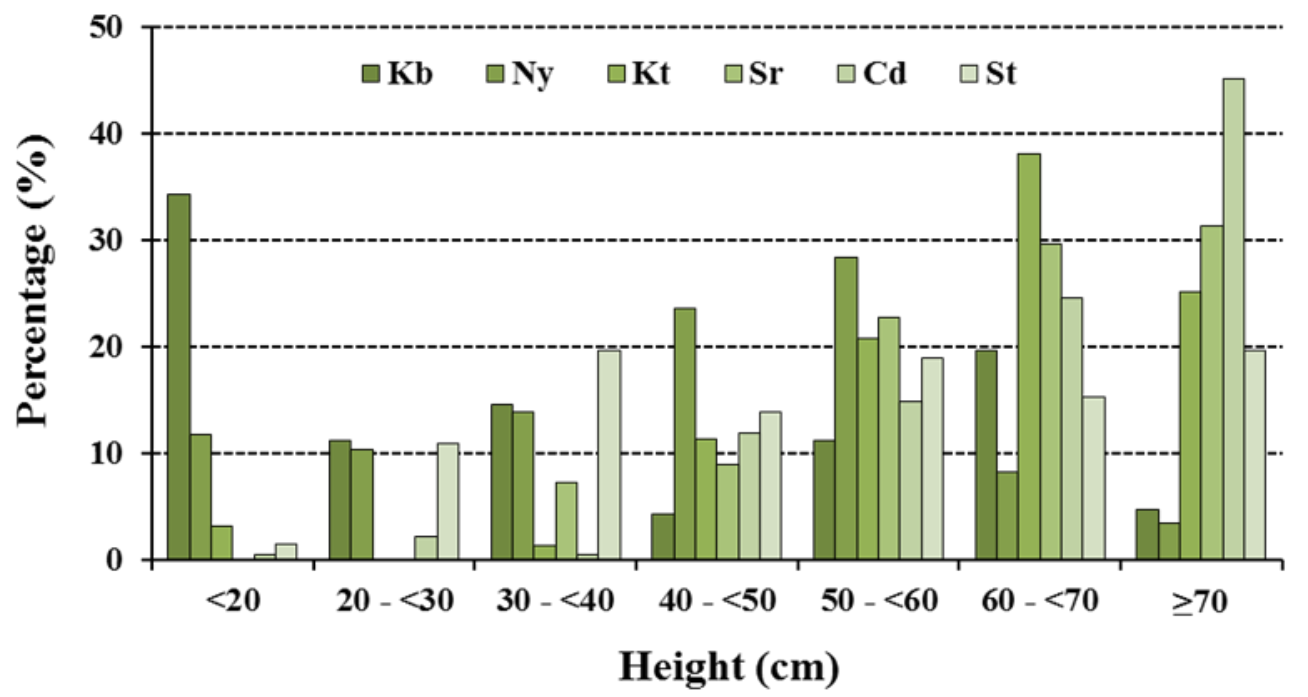

Fig. 3. Percentages of arrowroot heights $(\mathrm{cm})$, on six islands, Karimunjawa National Park, Central Java. Kumbang island $(\mathrm{Kb})$; Nyamuk island (Ny); Katang island (Kt); Seruni island $(\mathrm{Sr})$; Cendikia island $(\mathrm{Cd})$ and Sintok island (St).

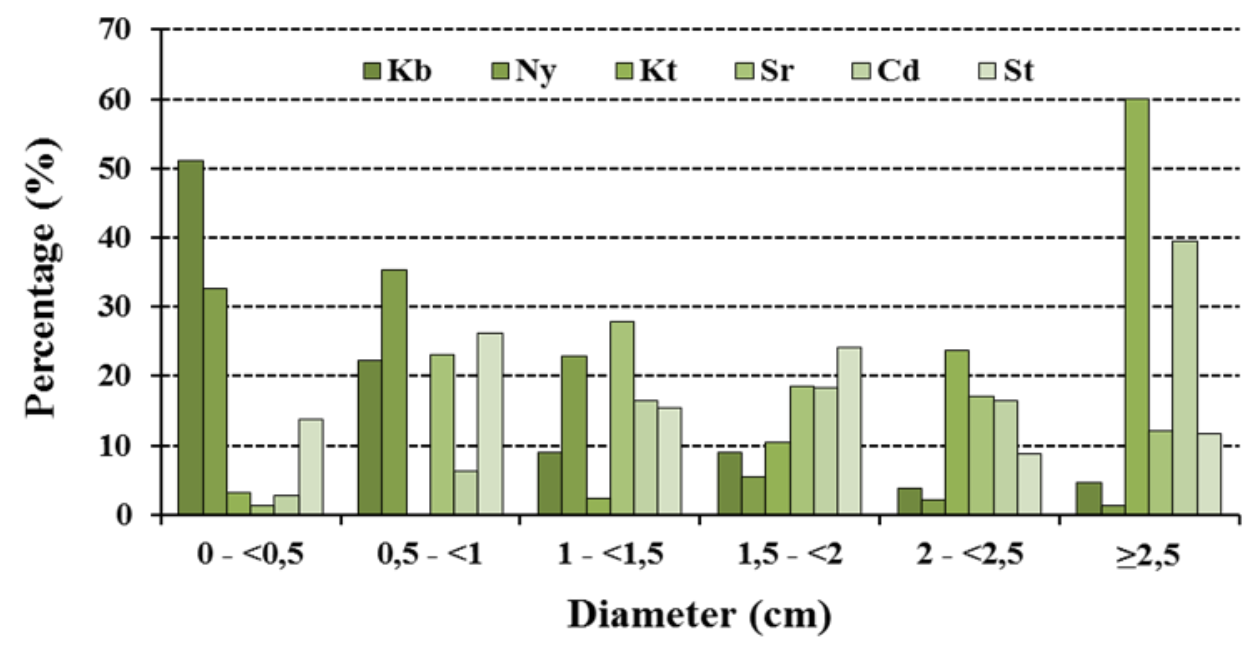

Fig. 4. Percentages of arrowroot diameters (cm), on six islands, Karimunjawa National Park, Central Java. Kumbang island (Kb); Nyamuk island (Ny); Katang island (Kt); Seruni island (Sr); Cendikia island (Cd); and Sintok island (St).

than $50 \%$ of the arrowroot had flowers and/ or fruits in each sampling area, except on Seruni where $70 \%$ of the arrowroot produced only fruits without flowers being found. The results showed that the height interval necessary for arrowroot to produce flowers/ fruits ranged from 40 to $120 \mathrm{~cm}$. Flower stems form together with the appearance of arrowroot leaves, and flowers will appear when the arrowroot leaves begin to fall. No flowers or fruits were recorded on Sintok island. Flowering arrowroot appeared on Kumbang, Katang and Cendikia islands, while on the other two islands, Nyamuk and Seruni, no flowers were found. As a perennial plant, it could be attributed that the previous three islands occurred a continuously generative phase and in the others were being in the last phase with producing only some fruits. Then, no flower/fruit was recorded in Sintok island due to the continuing vegetative phase of arrowroot.

Individual number of arrowroot, frequency and abundance in all sampling plots was much higher than those on other islands, such as in Madura and Kangean areas as investigated by Susiarti et al. (2011) and Susiarti et al. (2012), and on Krakatau island reported by Royyani et al. (2011). Those 
differences could be due to the presence of other shading plant species that grow surrounding arrowroot, also soil type and nutrient content of soil as well. In Madura, arrowroot was growing together with shading plants, such as Guettarda speciosa and Acacia maingayi, while on Kangean island the shading plants Schleichera oleosa and Guettarda speciosa were found by Susiarti et al. (2011). Royyani et al. (2011) stated that growing arrowroot was observed with Casuarina equisetifolia, Terminalia catappa and Hibiscus tiliaceus in Krakatau island. There were 30 species found in all sampling plots of the current study (Appendix 1). Among those species, using E(a) values, there are several species having a negative association with arrowroot, such as Sida acuta Chi-square count (cs) $>$ Chi-square table; $c s=5.71, \quad \mathrm{P}<0.05$ ) and Scaevola taccada (cs=7.94, $\mathrm{P}<0.01)$ on Kumbang island, Imperata cylindrical $(\mathrm{cs}=18.81, \mathrm{P}<0.01)$ in the Nyamuk island, and Morinda citrifolia (cs=9.47, $\mathrm{P}<0.01$ ) in Sintok island, indicating that the presence of arrowroot was high when the other species, such S. acuta, S. taccada, I. cylindrica and M. citrifolia was low. In contrary to Carica papaya $(\mathrm{cs}=3.95, \mathrm{P}<0.05)$ in Cendikia island has a positive association indicating that the occurence of $C$. papaya growing naturally has similar habitat on the presence of arrowroot.

Some other species surrounding arrowroot could indirectly affect the existence of arrowroot, although their existence have limited at each sampling plot. Furthermore, the other species found in the study plots varied, and there were only a few species found in almost all sampling areas, namely, Cocos nucifera, Premna corymbosa and Sida acuta. The last species, $S$. acuta was abundant and uniformly distributed in the sub-plots on Kumbang and Seruni islands. The other species were abundant, but their distribution tended to be clustered in one or two sub-plots, such as Guettarda speciosa on Kumbang island and Glochidion littorale on Seruni island.

The existence of other species around arrowroot greatly affected arrowroot growth when they appeared at the initial/vegetative phase of arrowroot, as the number of other plants was abundant with seedlings on Kumbang island. During the adult/generative phase, when the arrowroot plant produced some flowers and fruits, the plants did not really need other shading plants, of which only a few were found, as observed in Katang island.

The population of arrowroot and its correlation to soil nutrients is presented in Fig. 6. It shows that there was a distribution of arrowroot population in each site with soil nutrient, where the $\mathrm{N}, \mathrm{P}, \mathrm{K}, \mathrm{Mg}, \mathrm{C}$, and $\mathrm{Na}$ nutrients did not significantly affect the presence of arrowroot, as found in Kumbang, Nyamuk, Seruni and Sintok islands. In Cendikia island, calcium $(\mathrm{Ca})$ has influenced the arrowroot, while on Katang island the arrowroot population tended to be affected by potassium $(\mathrm{K})$ content. The correlation could be

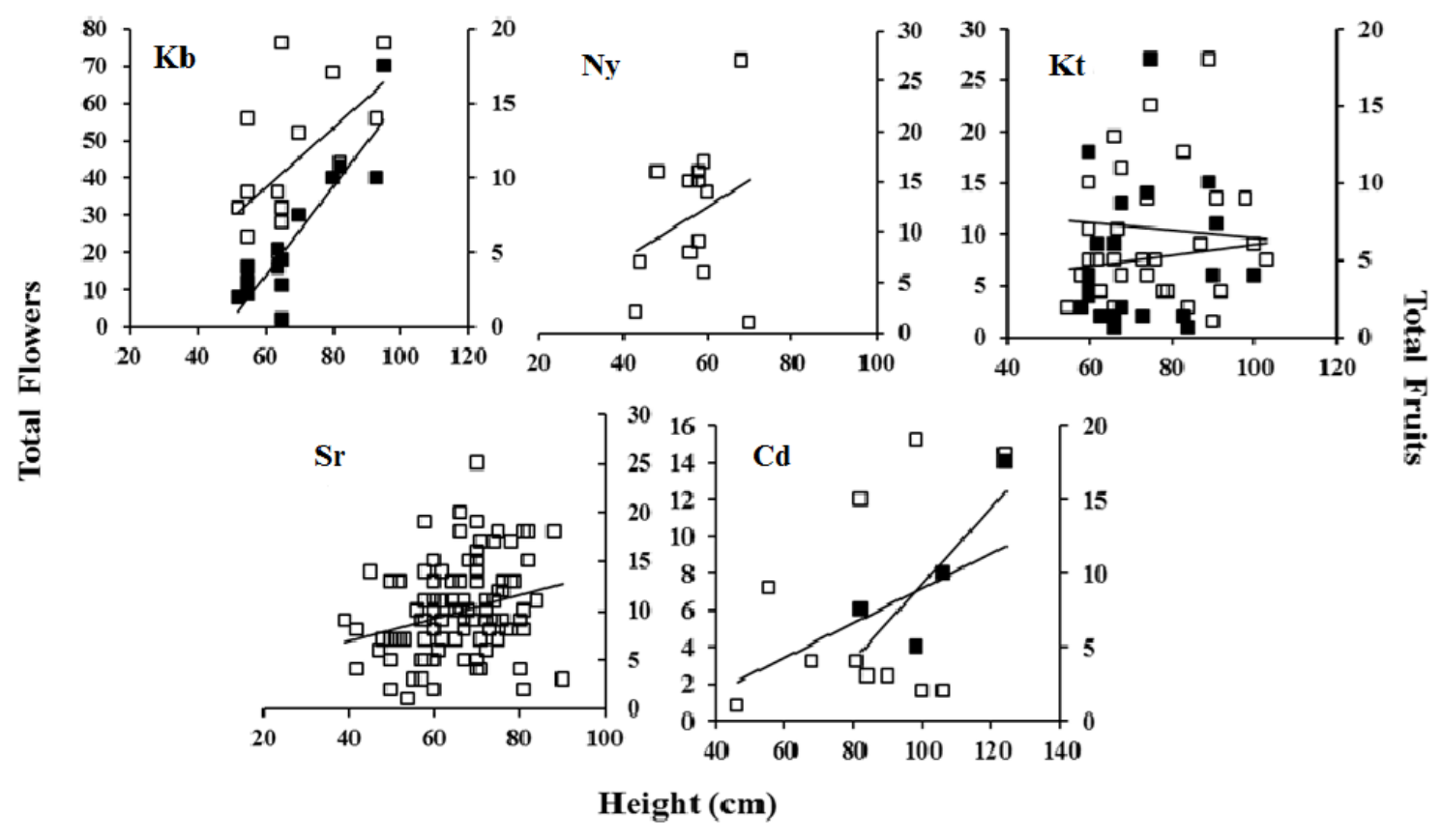

Fig. 5. Total flowers (closed squares; left) and fruits (open squares; right) in sampling areas, plotted against arrowroot height. $\mathrm{Kb}=$ Kumbang, $\mathrm{Ny}=$ Nyamuk, $\mathrm{Kt}=\mathrm{Katang}, \mathrm{Sr}=$ Seruni and $\mathrm{Cd}=$ Cendikia islands sampling plots. 


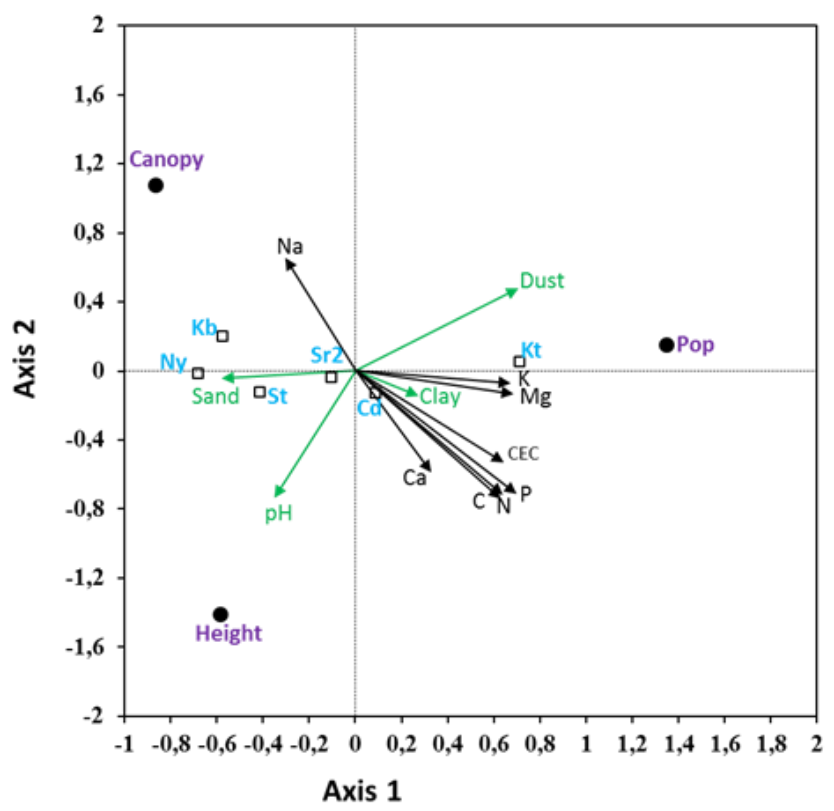

Fig. 6. The population (Pop) of arrowroot plant at each sampling sites, with soil nutrient components [pH, C (Carbon), N (Nitrogen), P (Phosphorus), Ca (Calcium), Mg (Magnesium), K (Potassium), Na (Sodium) and CEC (Cation Exchange Capacity)], using CCA (Canonical Correlation Analysis), at Karimunjawa NP, Central Java. The Kb, Ny, Kt, Sr, Cd and St are, respectively, Kumbang, Nyamuk, Katang, Seruni, Cendikia and Sintok islands.

attributed to the lower Ca reaching $22.1(\mathrm{cmol}(+)$ $\left.\mathrm{kg}^{-1}\right)$ with a bit lower in abundance in Cendikia island, and the ranging $\mathrm{K}$ value reached $0.2(\mathrm{cmol}$ $(+) \mathrm{kg}^{-1}$ ) with high abundance in Katang island.

Soil texture throughout the sampling plots consisted of the sandy type. The type was different from the texture of the soil of the arrowroot in other places (Susiarti et al., 2011; Susiarti et al., 2012). In East Java, the sandy content was lower than in the current study with soil type between the clay and loam (Susiarti et al., 2011). In Cendikia island, where one area had been cleaned/opened by means of combustion, large amounts of carbon loss occurred and contributed to organic matter content reaching $11.3 \%$ (C/N Ratio). Whereas in Sintok island was $11.6 \%$.

In addition, Canonical Correlation Analysis (CCA) clearly showed that the highest population was on Katang island, although the sandy content in the Island was a bit lower than the other islands. The sandy type characteristically has lower soil organic materials and will influence arrowroot growth, so for cultivation of the plant added organic matter is needed. Also, the low soil clay content could affect the Cation Exchange Capacity (CEC) and in this study CEC reached varily $3.5-7 \mathrm{cmol}(+) \mathrm{kg}^{-1}$. Generally to increase the arrowroot tuber production, it needs the proper condition such as within the vegetative and/or generative phases requires the shading plant for example Carica papaya, the soil texture must be high sandy with more than $90 \%$. For the nutrient content of soil is appropriate to arrowroot growth of $7.5-8(\mathrm{pH}), 2-2.5 \%(\mathrm{C}), 0.2 \%(\mathrm{~N})$, and $10-11$ ppm (P). Also the cation of $\mathrm{Ca}, \mathrm{Mg}, \mathrm{K}, \mathrm{Na}$, and CEC are, respectively, 22; $2-3 ; 0.2 ; 0.2-0.4$ and 5$5.5 \mathrm{cmol}(+) \mathrm{kg}^{-1}$.

\section{ACKNOWLEDGEMENTS}

We are grateful to the Head of the Botany Division and the Head of the Biology Research Center, LIPI for providing financial support. We also thank the Head of the Karimunjawa National Park for providing a research permit and his staff for providing facilities and assistance. We should acknowledge also the members of the research team led by Tutie Djarwaningsih for their cooperation during the field activities.

\section{REFERENCES}

ALHAMD, L. 2012. Biomassa tumbuhan taka (Tacca leontopetaloides) di sekitar Taman Nasional Karimunjawa, Jawa Tengah. In: MELATI, M., AZIS, S. A., EFENDI, D., ARMINI, N. M., SUDARSONO, EKANA'UL, N. \& AL TAPSI, S. (Eds.). Prosiding Simposium dan Seminar Bersama PERAGIPERHOTI-PERIPIHIGI. Mendukung kedaulatan pangan dan energi berkelanjutan. Departemen Agronomi dan Hortikultura, IPB, Bogor. Pp. 409-414. 
CHOZIN, M. A. 2012. Kedaulatan pangan yang berkelanjutan. In: MELATI, M., AZIS, S. A., EFENDI, D., ARMINI, N. M., SUDARSONO, EKANA'UL, N. \& AL TAPSI, S. (Eds.). Prosiding Simposium dan Seminar Bersama PERAGI-PERHOTI-PERIPI-HIGI. Mendukung kedaulatan pangan dan energi berkelanjutan. Departemen Agronomi dan Hortikultura, IPB, Bogor. Pp. 19-24.

LUDWIG, J. A. \& REYNOLD, J. F. 1988. Statistical Ecology. 2nd ed. Edward Arnold (Publisher) Co. Ltd., London.

MEENA, K. L. \& YADAV, B. L. 2010. Tacca leontopetaloides (Linn.) O. Kuntze (Taccaceae). A new record to the flora of Rajasthan. Indian Journal of Natural Products and Resources. 1 (4): 512-514.

MUELLER-DOMBOIS, D. \& ELLENBERG, H. 1974. Aims and Methods of Vegetation Ecology. John Willey and Sons. New York.

ROYYANI, M. F., PRATAMA, B. A. \& KARTONEGORO, A. 2011. Inventarisasi dan Karakterisasi Tanaman Pangan Lokal (Tacca leontopetaloides) di Kepulauan Krakatau, Lampung Selatan. Bidang Botani, Pusat Penelitian Biologi-LIPI, Bogor. Laporan Field-trip. 24 Pp. (Mimeograph).

SCHMIDT, F. H \& FERGUSON, J. H. A. 1951. Rainfall Types Based on Wet and Dry Period Rations for Indonesia with Western New Guinea. Jakarta: Kementrian Perhubungan Meteorologi dan Geofisika.

SPENNEMANN, D. H. R. 1994. Traditional arrowroot production and utilization in the Marshall Island. Journal Ethnobiology 14(2): 211-234.
SETYOWATI, N., SUSIARTI, S. \& RUGAYAH. 2012. Tacca leontopetaloides: Persebaran dan potensinya sebagai sumber pangan lokal di Jawa Timur. Jurnal Teknologi Lingkungan 31-40.

SUSIARTI, S., SETYOWATI, N., KOMARA, D. \& RUGAYAH. 2011. Eksplorasi dan Inventarisasi Tacca leontopetaloides (L.) dan Umbiumbian di Pulau Madura dan Beberapa Lokasi di Jawa Timur. Bidang Botani, Pusat Penelitian Biologi-LIPI. Laporan Field-trip. Pp. 32. (Mimeograph).

SUSIARTI, S., RUGAYAH, ERLINAWATI, I., SYARIF, F., SUHENDRA \& HAMZAH. 2012. Inventarisasi dan Populasi Studi Tacca leontopetaloides dan Ethnobotani dan Fisiologi, di Pulau Kangean, Sumenep, Jawa Timur. Bidang Botani, Pusat Penelitian Biologi -LIPI. Laporan Field-trip. Pp. 32. (Mimeograph).

TRIMANTO \& HAPSARI, L. 2016. Botanical survey in thirteen montane forests of Bawean Island Nature Reserve, East Java, Indonesia: Flora diversity, conservation status, and bioprospecting. Biodiversitas 17(2): 832-846.

WALTER, H. 1973. Vegetation of the Earth in Relation to Climate and the Eco-physiological conditions. Springer-Verlag, New York.

WAWO, A. H., LESTARI, P. \& UTAMI N. W. 2015. Studi perbanyakan vegetatif tanaman taka (Tacca leontopetaloides (L.) Kuntze dan pola pertumbuhannya. Berita Biologi 14(1): $1-9$. 
Appendix. Other plant species surrounding arrowroot, at Karimunjawa National Park, Central Java.

\begin{tabular}{|c|c|c|c|c|c|c|c|}
\hline \multirow{2}{*}{ No } & \multirow{2}{*}{ Species Name } & \multicolumn{6}{|c|}{ Location (Island) } \\
\hline & & $\mathbf{K b}$ & $\mathbf{N y}$ & Kt & $\mathrm{Sr}$ & Cd & St \\
\hline 1 & Aidia racemosa (Cav.) Tirveng. & $\sqrt{ }$ & $\sqrt{ }$ & & & $\sqrt{ }$ & $\sqrt{ }$ \\
\hline 2 & Amorphophallus muelleri Blume. & & $\sqrt{ }$ & & $\sqrt{ }$ & $\sqrt{ }$ & \\
\hline 3 & Ardisia humilis Vahl & & & & & & \\
\hline 4 & Buchanania arborescens (Blume) Blume. & $\sqrt{ }$ & & & & $\sqrt{ }$ & \\
\hline 5 & Carica papaya $\mathrm{L}$. & & & & $\sqrt{ }$ & $\sqrt{ }$ & \\
\hline 6 & Casuarina equisetifolia $\mathrm{L}$. & $\sqrt{ }$ & & $\sqrt{ }$ & & & \\
\hline 7 & Cocos nucifera $\mathrm{L}$ & $\sqrt{ }$ & $\sqrt{ }$ & $\sqrt{ }$ & $\sqrt{ }$ & $\sqrt{ }$ & \\
\hline 8 & Dioscorea hispida Dennst. & & & $\sqrt{ }$ & & & \\
\hline 9 & Ficus septica Burm.f. & & & & $\sqrt{ }$ & $\sqrt{ }$ & \\
\hline 10 & Glochidion rubrum Blume. & & $\sqrt{ }$ & & $\sqrt{ }$ & & $\sqrt{ }$ \\
\hline 11 & Glochidion littorale Blume. & & $\sqrt{ }$ & & $\sqrt{ }$ & $\sqrt{ }$ & $\sqrt{ }$ \\
\hline 12 & Guettarda speciosa $\mathrm{L}$. & $\sqrt{ }$ & & & $\sqrt{ }$ & $\sqrt{ }$ & \\
\hline 13 & Hibiscus tiliaceus Koord. & $\sqrt{ }$ & & & & & \\
\hline 14 & Imperata cylindrica (L.) Raeusch. & & $\sqrt{ }$ & $\sqrt{ }$ & & & $\sqrt{ }$ \\
\hline 15 & Ixora paludosa (Blume.) Kurz & $\sqrt{ }$ & & & & $\sqrt{ }$ & $\sqrt{ }$ \\
\hline 16 & Litsea accedentoides Koords. \& Valeton & $\sqrt{ }$ & & & & & $\sqrt{ }$ \\
\hline 17 & Litsea glutinosa (Lour.) C.B.Rob. & $\sqrt{ }$ & & & & & $\sqrt{ }$ \\
\hline 18 & Morinda citrifolia $\mathrm{L}$. & & & $\sqrt{ }$ & & $\sqrt{ }$ & $\sqrt{ }$ \\
\hline 19 & Nephrolepis biserrata (Sw.) Schott & & & & & $\sqrt{ }$ & \\
\hline 20 & Pandanus tectorius Parkinson ex Du Roi & $\sqrt{ }$ & & & & & \\
\hline 21 & Passiflora foetida $\mathrm{L}$. & & $\sqrt{ }$ & & & & \\
\hline 22 & Physalis minima $\mathrm{L}$. & & $\sqrt{ }$ & & & & \\
\hline 23 & Planchonella nitida (Blume.) Dubard & $\sqrt{ }$ & & & & & \\
\hline 24 & Polygala paniculata $\mathrm{L}$. & $\sqrt{ }$ & $\sqrt{ }$ & & & & \\
\hline 25 & Premna corymbosa Rottler \& Willd. & $\sqrt{ }$ & $\sqrt{ }$ & $\sqrt{ }$ & $\sqrt{ }$ & & $\sqrt{ }$ \\
\hline 26 & Rhus taitensis Guill. & $\sqrt{ }$ & & $\sqrt{ }$ & & & \\
\hline 27 & Scaevola taccada (Gaertn.) Roxb. & $\sqrt{ }$ & $\sqrt{ }$ & & & & $\sqrt{ }$ \\
\hline 28 & Sida acuta Burm.f. & $\sqrt{ }$ & & $\sqrt{ }$ & $\sqrt{ }$ & $\sqrt{ }$ & $\sqrt{ }$ \\
\hline 29 & Terminalia catappa $\mathrm{L}$. & $\sqrt{ }$ & & & & $\sqrt{ }$ & \\
\hline 30 & Wedelia biflora (L.) DC. & & & & & $\sqrt{ }$ & \\
\hline
\end{tabular}

Note: $\mathrm{Kb}=$ Kumbang; $\mathrm{Ny}=$ Nyamuk; $\mathrm{Kt}=$ Katang; $\mathrm{Sr}=$ Seruni; $\mathrm{Cd}=$ Cendikia and $\mathrm{St}=$ Sintok 


\section{INSTRUCTION TO AUTHORS}

Scope. Reinwardtia is a scientific regular journal on plant taxonomy, plant ecology and ethnobotany published in June and December. Manuscript intended for a publication should be written in English.

Titles. Titles should be brief, informative and followed by author's name and mailing address in oneparagraphed.

Abstract. English abstract followed by Indonesian abstract of not more than 250 words. Keywords should be given below each abstract.

Manuscript. Manuscript is or iginal paper and represent an article which has not been published in any other journal or proceedings. The manuscript of no more than 36 pages by using Times New Roman 11, MS Word for Windows of A4 with double spacing, submitted to the editor through Reinwardtia online journal system and < reinwardtia@mail.lipi.go.id>. New paragraph should be indented in by 5 characters. For the style of presentation, authors should follow the latest issue of Reinwardtia very closely. Author(s) should send the preferred running title of the article submitted. Every manuscript will be sent to two blind reviewers.

Identification key. Taxonomic identification key should be prepared using the aligned couplet type.

Nomenclature. Strict adherence to the International Code of Nomenclature is observed, so that taxonomic and nomenclatural novelties should be clearly shown. English description for new taxon proposed should be provided and the herbaria where the type specimens area deposited should be presented. Name of taxon in taxonomic treatment should be presented in the long form that is name of taxon, author's name, year of publication, abbreviated journal or book title, volume, number and page.

Map/line drawing illustration/photograph. Map, line drawing illustration, or photograph preferably should be prepared in landscape presentation to occupy two columns. Illustration must be submitted as original art accompanying, but separated from the manuscript. The illustration should be saved in JPG or GIF format at least 350 pixels. Legends or illustration must be submitted separately at the end of the manuscript.

References. Bibliography, list of literature cited or references follow the Harvard system as the following examples.

Journal : KRAENZLIN, F. 1913. Cyrtandraceae novae Philippinenses I. Philipp. J. Sci. 8: 163-179.

MAYER, V., MOLLER, M., PERRET, M. \& WEBER, A. 2003. Phylogenetic position and generic differentiation of Epithemateae (Gesneriaceae) inferred from plastid DNA sequence data. American J. Bot. 90: 321-329.

Proceedings : TEMU, S. T. 1995. Peranan tumbuhan dan ternak dalam upacara adat "Djoka Dju" pada suku Lio, Ende, Flores, Nusa Tenggara Timur. In: NASUTION, E. (Ed.). Prosiding Seminar dan Lokakarya Nasional Etnobotani II. LIPI \& Perpustakaan Nasional: 263-268. (In Indonesian).

SIMBOLON, H. \& MIRMANTO, E. 2000. Checklist of plant species in the peat swamp forests of Central Kalimantan, Indonesia. In: IWAKUMA, T., INOUE, T., KOHYAMA, T., OSAKI, M., SIMBOLON, H., TACHIBANA, H., TAKAHASHI, H., TANAKA, N., YABE, K. (Eds.). Proceedings of the International Symposium on: Tropical Peatlands. Pp.179 - 190.

Book : RIDLEY, H. N. 1923. Flora of the Malay Peninsula 2. L. Reeve \& Co. Ltd, London.

Part of Book : BENTHAM, G. 1876. Gesneriaceae. In: BENTHAM, G. \& HOOKER, J. D. Genera Plantarum 2. Lovell Reeve \& Co., London. Pp. 990-1025.

Thesis : BAIRD, L. 2002. A Grammar of Kéo: An Austronesian Language of East Nusantara. Australian National University, Canberra. [PhD. Thesis].

Website : http://www.nationaalherbarium.nl/fmcollectors/k/KostermansAJGH.html. (Accessed 15 February 2012). 


\section{Reinwardtia}

Published by Herbarium Bogoriense, Botany Division, Research Center for Biology, Indonesian Institute of Sciences

Address: Jln. Raya Jakarta-Bogor Km. 46 Cibinong 16911, P.O. Box 25 Cibinong

Telp. (+62) 21 8765066; Fax (+62) 218765062

LIPI

Email: reinwardtia@mail.lipi.go.id

\section{REINWARDTIA Author Agreement Form}

Title of article

Name of Author(s) :

I/We hereby declare that:

- $\mathrm{My} / \mathrm{Our}$ manuscript was based on my/our original work.

- It was not published or submitted to other journal for publication.

- I/we agree to publish my/our manuscript and the copyright of this article is owned by Reinwardtia.

- We have obtained written permission from copyright owners for any excerpts from copyrighted works that are included and have credited the sources in our article. 



\section{REINWARDTIA}

Vol. 17. No. 2. 2018

CONTENTS

LAODE ALHAMD. Ecological study of the arrowroot (Tacca leontopetaloides (L.) Kuntze) at Karimunjawa National Park (KNP), Central Java

YASPER MICHAEL MAMBRASAR \& PRIMA W. K. HUTABARAT. Rhododendron meagaii, a new species of Rhododendron subgenus Vireya (Ericaceae) from Papua, Indonesia

K. M. WONG, RIDHA MAHYUNI, XIN YI NG \& LOUISE NEO. Flora of Singapore Precursors, 8. Systematy of the new Southeast Asian genera Canthiumera and Dibridsonia (Rubiaceae: Vanguerieae), with notes on plant architecture and reproductive ecology

ANDREW POWLING. An assessment of present plant diversity on the Natewa Peninsula, Vanua Levu, Fiji 125

ASEP SADILI, KUSWATA KARTAWINATA, HERWASONO SOEDJITO \& EDY NASRIADI SAMBAS. Tree species diversity in a pristine montane forest previously untouched by human activities in Foja Mountains, Papua, Indonesia

Reinwardtia is a LIPI accredited Journal (792/AU3/P2MI-LIPI/04/2016)

http://e-journal.biologi.lipi.go.id/index.php/reinwardtia

Herbarium Bogoriense

Botany Division

Research Center for Biology - Indonesian Institute of Sciences

Cibinong Science Center

Jln. Raya Jakarta - Bogor, Km 46

Cibinong 16911, P.O. Box 25 Cibinong

Indonesia 